\title{
Neglected obstetric haemorrhage leading to acute kidney injury
}

\author{
Pallavi Verma ${ }^{1 *}$, Pavitra M. Dogra ${ }^{2}$, Shivendra K. Sinha ${ }^{3}$, \\ Ramesh Kaushik $^{4}$, Davinder Bhardwaj ${ }^{1}$
}

${ }^{1}$ Department of Obstetrics and Gynecology, ${ }^{2}$ Department of Nephrology, ${ }^{3}$ Department of Orthopedics, ${ }^{4}$ Commandant, Military Hospital, Jalandhar Cantt, Punjab, India

Received: 12 September 2017

Accepted: 05 October 2017

*Correspondence:

Dr. Pallavi Verma,

E-mail: drpallavi4@gmail.com

Copyright: (C) the author(s), publisher and licensee Medip Academy. This is an open-access article distributed under the terms of the Creative Commons Attribution Non-Commercial License, which permits unrestricted non-commercial use, distribution, and reproduction in any medium, provided the original work is properly cited.

\begin{abstract}
Pregnancy related acute kidney injury takes substantial share of acute kidney injury (AKI) in India, with obstetrical haemorrhage having high morbidity and mortality. A young female had neglected obstetric haemorrhage (unrecognized intrauterine and massive intraperitoneal bleeding post caesarean, due to uterine trauma and atony) and dangerous intra-abdominal hypertension with exsanguination eventually leading to shock, multifactorial AKI, metabolic acidosis, and hyperkalemia. Intensive and aggressive management with subtotal hysterectomy, inotropes, fluid management, mechanical ventilation, tracheostomy, and hemodialysis changed the outcome. Despite odds against, neglected obstetric haemorrhage with complicated AKI, was managed successfully by emergency hysterectomy, aggressive intervention for AKI with intensive fluid, ventilatory management and daily hemodialysis. Timely identification and aggressive management of this condition and complications is pivotal in preventing complications, morbidity, and maternal mortality.
\end{abstract}

Keywords: Acute kidney injury, Hemodialysis, Obstetric haemorrhage

\section{INTRODUCTION}

Pregnancy related acute kidney injury (PR-AKI) takes a substantial share of acute kidney injury (AKI) in India, the incidence varying from $7-14.5 \% .^{1-4}$ Its contribution is striking in developing world, due to ignorance and late presentation of the patient, the incidence thereof is now decreasing with better awareness and medical expertise.

Obstetric Haemorrhage $(\mathrm{OH})$ with hypertension and infections is one of the killer 'triad' in pregnancy in both developed and underdeveloped countries and is the leading cause for to intensive care units (ICU) admissions in obstetrics. ${ }^{5}$ PR-AKI due to $\mathrm{OH}$ in Indian subcontinent is reported as $17-60.9 \% .^{6,7} \mathrm{PR}-\mathrm{AKI}$ related maternal mortality is showing decreasing trend in India. ${ }^{1,2} \mathrm{We}$ report a complicated case of a young female with neglected obstetric Haemorrhage (unrecognized intrauterine and massive intraperitoneal bleeding post caesarean) due to uterine trauma and atony thereby causing dangerous intra-abdominal hypertension and exsanguination eventually leading to shock and multifactorial PR-AKI. Timely aggressive and intensive management changed the outcome of this condition.

\section{CASE REPORT}

Our patient, a 29 years P3L3, underwent lower section caesarean section (LSCS) for non-progression of labour at private clinic in Class II city. After few hours of caesarean, she noticed progressive painful distension of abdomen with reducing urine output, and extreme fatigue. She was managed conservatively for $24 \mathrm{hrs}$ with intravenous fluids and antibiotics and referred to our 
hospital for further management due to gradual deteriorating patient's general condition. Investigations done on post operative 2 days revealed hemoglobin $(\mathrm{Hb})$ $4.2 \mathrm{gm} / \mathrm{dL}$, total leucocyte count (TLC) $26500 / \mathrm{mm}^{3}$ with polymorphonuclear predominance, blood urea $206 \mathrm{mg} / \mathrm{dl}$, serum creatinine $5.9 \mathrm{mg} / \mathrm{dl}$, serum sodium $(\mathrm{Na}+) 145$
$\mathrm{mEq} / \mathrm{L}$, serum potassium $(\mathrm{K}+) 6.9 \mathrm{mEq} / \mathrm{L}$. Ultrasound showed large intraperitoneal fluid collection and enlarged hyper-echoic kidneys. She came on transfer to our hospital in critical condition on inotropes and oxygen support.

Table 1: Hematological and biochemistry parameters during hospital stay.

\begin{tabular}{|c|c|c|c|c|}
\hline Investigations & $\begin{array}{l}\text { 26/12/16 (On } \\
\text { admission) }\end{array}$ & $\begin{array}{l}\text { 28/12/16 (Post } \\
\text { Op Day 3) }\end{array}$ & $\begin{array}{l}\text { 04/01/17 (Post } \\
\text { Op Day 10) }\end{array}$ & $\begin{array}{l}\text { On } \\
\text { Discharge }\end{array}$ \\
\hline $\mathrm{Hb}(\mathrm{gm} / \mathrm{dl})$ & 4.2 & 7.3 & 10.5 & 11.2 \\
\hline TLC (per cu mm) & 26,500 & 18,100 & 13,300 & 4,000 \\
\hline DLC & P96L2M1E1 & P93L5M1E1 & P88L5M2E5 & P68L28M2E2 \\
\hline Platelet Count (per cu mm) & 96,000 & 95,000 & $1,88,000$ & \\
\hline S.Creatinine $(\mathrm{mg} / \mathrm{dl})$ & 5.9 & 4.6 & 6.5 & 1.2 \\
\hline S.Urea $(\mathrm{mg} / \mathrm{dl})$ & 206 & 102 & 126 & 35 \\
\hline S. Bilirubin $(\mathrm{mg} / \mathrm{dl})$ & 2.8 & 1.9 & 0.8 & 0.6 \\
\hline S. Protein/Albumin (gm/dl) & $3.8 / 1.7$ & $4.2 / 2.0$ & $5.9 / 2.8$ & $5.9 / 3.8$ \\
\hline SGOT (units/l) & 754 & 111 & 55 & 40 \\
\hline SGPT (units/l) & 232 & 84 & 42 & 36 \\
\hline LDH (units/lit) & 8480 & 5968 & 682 & 268 \\
\hline PT & $13 / 20$ & $13 / 15$ & & \\
\hline INR & 1.5 & 1.1 & 1.8 & 1.2 \\
\hline PTTK & 28/35 & & & \\
\hline S. Sodium $(\mathrm{meq} / \mathrm{l})$ & 145 & 136 & 138 & 138 \\
\hline S.Potassium (meq/l) & 6.9 & 3.8 & 4.2 & 4.3 \\
\hline S. Calcium (mg/dl) & 7 & 8 & 8.4 & 8.6 \\
\hline
\end{tabular}

At admission, she had dyspnoea, painful abdominal distension and nil urine output. She was drowsy, had kussmaul respiration with respiratory rate of 14 per minute, pulse 148 per minute, blood pressure $76 / 40 \mathrm{~mm}$ of $\mathrm{Hg}$, gross pallor, $\mathrm{SpO} 286 \%$ on inhaled oxygen, empty urinary collection bag and bilateral infrascapular pulmonary crackles. Abdomen was tense and tender with absent bowel sounds. Per vaginal examination revealed more than normal bleed. Investigations (Table 1) revealed $\mathrm{Hb} 3.8 \mathrm{gm} / \mathrm{dL}$, TLC $26200 / \mathrm{mm} 3$ with polymorphs predominance, blood urea $257 \mathrm{mg} / \mathrm{dl}$, serum creatinine $6.3 \mathrm{mg} / \mathrm{dl}, \mathrm{Na}+146 \mathrm{mEq} / \mathrm{L}$ and $\mathrm{K}+6.8 \mathrm{mEq} / \mathrm{L}$. Her serum bilirubin $3.2 \mathrm{mg} / \mathrm{dl}$, conjugated bilirubin $0.5 \mathrm{mg} / \mathrm{dl}$, serum AST 568 IU/L, serum ALT 792 IU/L, PT with INR 1.8, arterial $\mathrm{pH}-7.18$, serum bicarbonate-7 $\mathrm{mEq} / \mathrm{L}$ and a base excess of -19.2 , thus suggesting severe metabolic acidosis. Ultrasound showed irregular heteroechoic lesion (hematoma) $9.2 \times 9.4 \times 5.7 \mathrm{~cm}$ anterior to lower uterine segment and significant intra-peritoneal collection, aspiration showed blood. She had abdominal compartment syndrome (ACS); intra-abdominal pressure (IAP) was 24 centimeters of $\mathrm{H} 2 \mathrm{O}$ suggesting grade 3 intra-abdominal hypertension (IAH).

In view of hyperkalemia, metabolic acidosis, advanced azotemia, and anuria, preoperative emergency hemodialysis with inotropic support and transfusion of two units of packed RBCs (PRBCs) and four units of fresh frozen plasma (FFPs) was conducted to stabilize electrolytes, uraemia, acidosis and uremic platelet dysfunction, followed by emergency exploratory laparotomy under general anaesthesia.

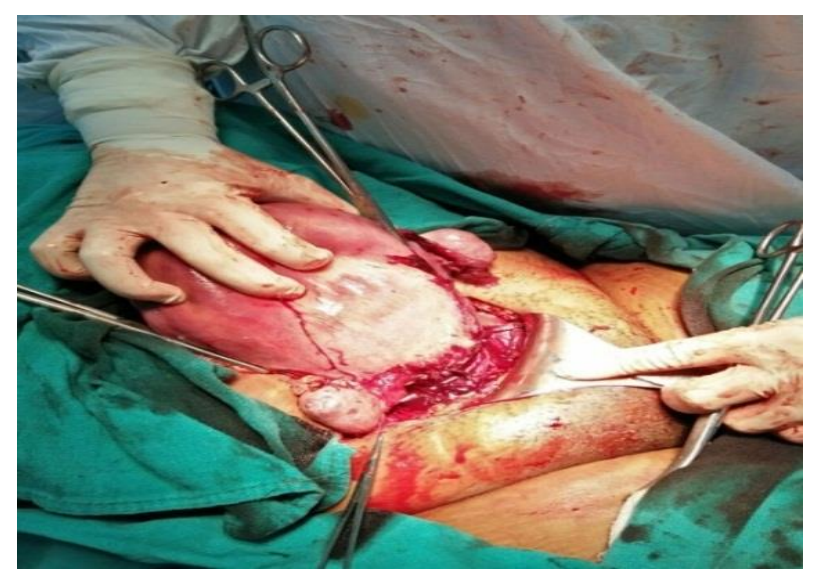

Figure 1: Uterus is totally flabby, atonic and few necrotic patches are seen.

Per-operative assessment showed hemoperitoneum (approximately 2.0 litres), large hematoma of $10 \times 9 \times 5$ $\mathrm{cm}$ size between bladder and lower uterine segment, and 
a necrotic flabby uterus (Figure 1) with generalized bleeding at uterine sutures (Figure 2) and one suture passing through the right uterine artery.

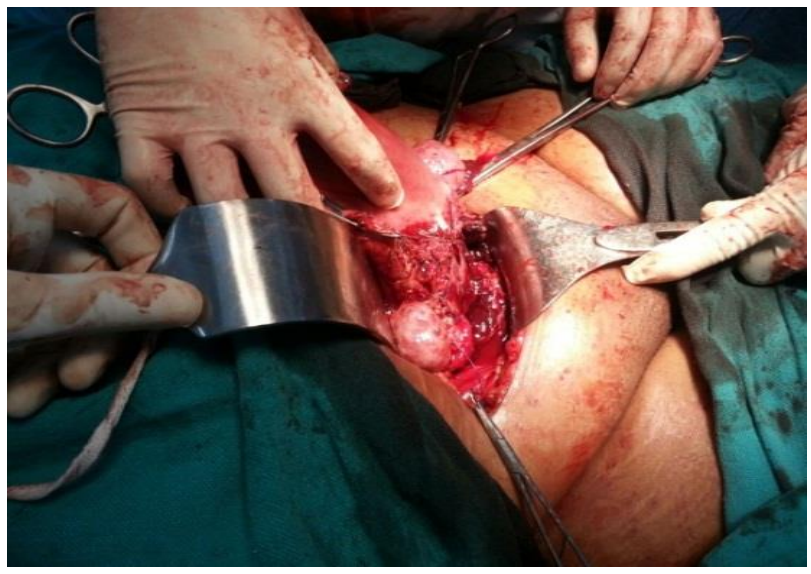

Figure 2: Bleeding seen coming through whole of uterine suture line.

She underwent evacuation of hematoma, drainage of hemoperitoneum and subtotal hysterectomy (Figure 3) and three PRBCs and four FFPs transfusion.

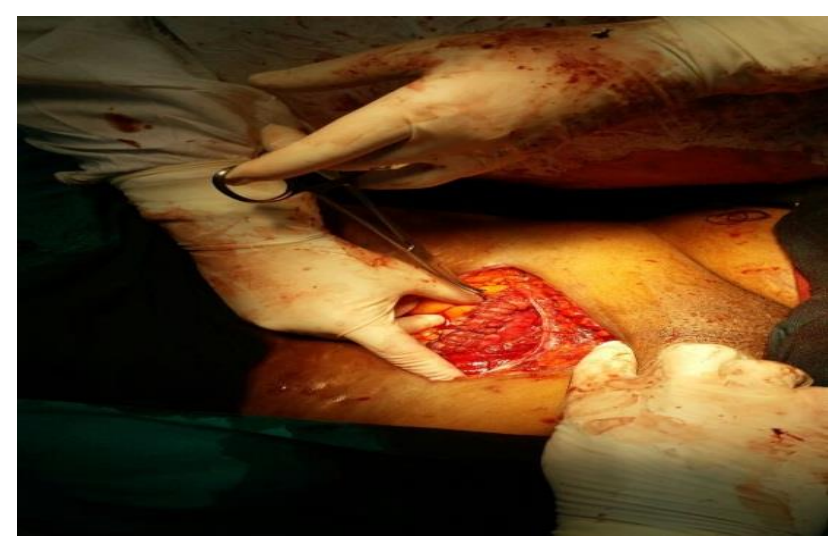

Figure 3: Healthy vault after subtotal hysterectomy.

Ureters and urinary bladder were intact. Management in ICU consisted of mechanical ventilation, inotropes, antibiotics, fluid restriction, 8 units PRBCs, 12 units FFPs transfusion, and intermittent hemodialysis. She underwent tracheostomy due to anticipated prolonged intubation. Weaning off mechanical ventilator, inotropes and underwent extubation was done on day 9. Decannulation of tracheostomy tract occurred in next 4 days. Urine output gradually improved and she became dialysis independent after 15 sessions of hemodialysis. Her renal parameters returned to normal and anaemia responded to hematinics. She went on discharge at day29.

\section{DISCUSSION}

$\mathrm{OH}$ is the commonest cause of maternal mortality worldwide. It causes annual maternal mortality of $30 \%$; equivalent 86000 deaths per year and approximately 10 deaths every hour. ${ }^{8}$ In present case, PR-AKI, a dreaded complication of $\mathrm{OH}$ occurred due to prolonged hypotension, sepsis and ACS. AKI has long replaced acute renal failure and labeled as per RIFLE or AKIN criteria. $^{9}$

The incidence of pregnancy related acute kidney injury is $1.0 \%-2.8 \%$ in developed countries compared to $4 \%-26 \%$ in developing countries. ${ }^{10}$ Although the incidence of PRAKI is decreasing worldwide, it is still the major contributor to significant morbidity and mortality in developing world. ${ }^{11}$

Present case improved after emergent management of uterine bleed and intensive dialysis support, the incidence of Dialysis requiring PR-AKI has reduced. However, acute renal ischemia is still major risk associated with severe pre-eclampsia and Haemorrhage, other factors being HELLP syndrome, abruption placentae, septicemia, acute fatty liver of pregnancy, severe hyperemesis gravidarum. ${ }^{12}$ In present case, unattended massive post caesarean Haemorrhage resulting in fluid unresponsive hypotension, ACS and septicemia caused PR-AKI.

PR-AKI due to $\mathrm{OH}$ is preventable by early diagnosis of initial Haemorrhage; prompt volume replacement with crystalloids or blood and early medical and surgical intervention. Early fluid or blood replacement can prevent acute cortical necrosis by maintaining adequate renal perfusion. Observation for early signs of sepsis syndrome, avoidance of loop diuretics (assess fluid status) and judicious use of vasoconstrictors are other important steps. Early hemodialysis is mandatory if lifethreatening complications as hyperkalemia, refractory metabolic acidosis and fluid overload related pulmonary edema prevail.

\section{CONCLUSION}

PR-AKI is a critical condition, which requires emergent intervention and tackling addressable cause early. Despite reducing incidence, it prevails as an important cause of morbidity and mortality in India.

The most effective method of dealing with this lifethreatening situation is prevention; it is possible through provision and promotion of high quality and accessible antenatal care with extensive obstetrics facilities, early detection and diagnosis of the condition, and timely management of obstetrics complications. Early identification and effective management of $\mathrm{OH}$ is pivotal to prevent complications and further maternal morbidity and mortality and timely intervention for AKI with volume replenishment and renal replacement therapy can be fruitful.

\section{Funding: No funding sources \\ Conflict of interest: None declared \\ Ethical approval: Not required}




\section{REFERENCES}

1. Chugh KS, Sakhuja V, Malhotra HS, Pereira BJ. Changing trends in acute renal failure in third world countries- Chandigarh study. Q J Med. 1989;272:1117-23.

2. Kilari SK, Chinta RK, Vishnubhotla SK. Pregnancy related acute renal failure. J Obstet Gynecol India. 2006;56:308-10.

3. Rani PU, Narayen GA. Changing trends in pregnancy related acute renal failure. J Obstet Gynecol India. 2002;52:36-8.

4. Najar MS, Shah AR, Wani IA, Reshi AR, Banday KA, Bhat MA, et al. Pregnancy related acute kidney injury: A single center experience from the Kashmir Valley. Indian J Nephrol. 2008 Oct;18(4):159-161.

5. Small MJ, James AH, Kershaw T, Thames B, Gunatilake R, Brown H. Near miss maternal mortality: cardiac dysfunction as the principal cause of obstetric intensive care admissions. Obstet Gynecol. 2012;119(2 Pt 1):250.

6. Kumar KS, Krishna CR, Kumar VS. Pregnancy related acute renal failure. J Obstet Gynecol India 2006;56:308-10.
7. Pahwa N, Bharani R, Kumar R. Post-Partum Acute Kidney Injury. Saudi J Kidney Dis Transpl 2014;25(6):1244-7.

8. Weeks A. The prevention and treatment of postpartum haemorrhage: what do we know, and where do we go to next?. BJOG. 2015;122(2):20210 .

9. American Society of Nephrology Renal Research Report. J Am Soc Nephrol. 2005;16:1886-903.

10. Gammill HS, Jeyabalan A. Acute renal failure in pregnancy. Crit Care Med 2005;33(10 Suppl):S37284.

11. Kuklina EV, Meikle SF, Jamieson DJ, Whiteman MK, Barfield WD, Hillis SD et al. Severe obstetrics morbidity in the United States: 1998-2005. Obstet Gynecol. 2009;113:293.

12. Acharya A, Santos J, Linde B, Anis K. Acute kidney injury in pregnancy-current status. Adv Chronic Kidney Dis. 2013;20:215.

Cite this article as: Verma P, Dogra PM, Sinha SK, Kaushik R, Bhardwaj D. Neglected obstetric haemorrhage leading to acute kidney injury. Int $\mathbf{J}$ Reprod Contracept Obstet Gynecol 2017;6:5177-80. 